\title{
Suppression of Serotonin Neuron Firing Increases Aggression in Mice
}

\author{
Enrica Audero, ${ }^{1,3}$ Boris Mlinar, ${ }^{2}$ Gilda Baccini, ${ }^{2}$ Zhiva K. Skachokova, ${ }^{1}$ Renato Corradetti, ${ }^{2}$ and Cornelius Gross ${ }^{1}$ \\ ${ }^{1}$ Mouse Biology Unit, European Molecular Biology Laboratory, 00015 Monterotondo, Italy, ${ }^{2}$ Department of Preclinical and Clinical Pharmacology, University of \\ Florence, 50139 Firenze, Italy, and ${ }^{3}$ Champalimaud Neuroscience Programme, Champalimaud Centre for the Unknown, 1400-038 Lisboa, Portugal
}

Numerous studies link decreased serotonin metabolites with increased impulsive and aggressive traits. However, although pharmacological depletion of serotonin is associated with increased aggression, interventions aimed at directly decreasing serotonin neuron activity have supported the opposite association. Furthermore, it is not clear if altered serotonin activity during development may contribute to some of the observed associations. Here, we used two pharmacogenetic approaches in transgenic mice to selectively and reversibly reduce the firing of serotonin neurons in behaving animals. Conditional overexpression of the serotonin $1 \mathrm{~A}$ receptor (Htrla) in serotonin neurons showed that a chronic reduction in serotonin neuron firing was associated with heightened aggression. Overexpression of Htrla in adulthood, but not during development, was sufficient to increase aggression. Rapid suppression of serotonin neuron firing by agonist treatment of mice expressing Htrla exclusively in serotonin neurons also led to increased aggression. These data confirm a role of serotonin activity in setting thresholds for aggressive behavior and support a direct association between low levels of serotonin homeostasis and increased aggression.

\section{Introduction}

Studies across a wide range of metazoan species have identified the brain neurotransmitter serotonin (5-HT) as a major modulator of impulsive and aggressive behavior. Reduced CSF levels of the serotonin metabolite 5-hydroxyindole acetic acid (5-HIAA) have been found in aggressive psychiatric patients, suicide victims and impulsive, violent men (Brown et al., 1982; Linnoila et al., 1983; Virkkunen et al., 1994). A similar negative association between serotonin metabolites and aggressive behavior has been reported in a wide range of species, including macaques (Mehlman et al., 1994), mice (Caramaschi et al., 2007), and fish (Clotfelter et al., 2007), suggesting a causal link between reduced serotonin activity and aggression. Such a causal link is supported by pharmacological studies in which aggression is increased by depletion of tryptophan, an essential precursor of serotonin (Chamberlain et al., 1987; Bjork et al., 1999), or inhibition of serotonin synthesis (Vergnes et al., 1986).

Genetic variants in the rate-limiting enzymes in serotonin synthesis and metabolism, tryptophan hydroxylase 2 (TPH2) and

\footnotetext{
Received April 30, 2012; revised April 9, 2013; accepted April 11, 2013.

Author contributions: E.A., B.M., R.C., and C.G. designed research; E.A., B.M., G.B., and Z.K.S. performed research; R.C. and C.G. contributed unpublished reagents/analytic tools; E.A., B.M., G.B., Z.K.S., R.C., and C.G. analyzed data; E.A. and C.G. wrote the paper.

This work was supported by funds from European Molecular Biology Laboratory (EMBL) (E.A., Z.K.S., C.G.) and grants from the European Commission (FP7 DEVANX; C.G.), Compagnia San Paolo (Programma Neuroscienze2008.2265; R.C.), and Regione Toscana (Ricerca Regionale in Materia di Salute 2009-Project 82; R.C.). We thank Jeanette Rientjes and Theodoros Tsetsenis for cloning the Tph2-Htr1a construct; Francesca Zonfrillo and Stefania Rizzo for animal husbandry; Olga Schubert for help in behavioral testing; and Jose Gonzalez and the EMBL Transgenic Facility for animal production.

Correspondence should be addressed to Cornelius Gross, Mouse Biology Unit, EMBL, Via Ramarini 32, 00015 Monterotondo (RM), Italy. E-mail: gross@embl.it.

DOI:10.1523/JNEUROSCI.2067-12.2013

Copyright $\odot 2013$ the authors $\quad 0270-6474 / 13 / 338678-11 \$ 15.00 / 0$
}

monoamine oxidase A (MAOA), respectively, have been associated with increased aggression in humans, macaques, and mice (Brunner et al., 1993; Manuck et al., 1999; Huang et al., 2004; Newman et al., 2005; Osipova et al., 2009). However, while the pharmacological experiments suggest a negative association between serotonin neurotransmission and aggression, the genetic studies are equivocal with decreased synthesis and decreased degradation of serotonin both being linked to similar behavioral changes. Discrepancies in genetic data may come from the compensatory role of multiple feedback mechanisms that maintain serotonin homeostasis.

The simple association between low serotonin activity and increased aggression has been challenged by data showing that direct injection into the dorsal raphe nucleus of agonists for Htrla, the receptor which provide direct negative feedback on the firing and release of serotonin, leads to decreased aggressive behavior in rats (Mos et al., 1993; De Almeida and Lucion, 1997; van der Vegt et al., 2003). Furthermore, pharmacological agonists of Htrla receptors have been shown to decrease aggressive behavior in resident mice (Miczek et al., 1998; de Boer et al., 2000; de Boer and Koolhaas, 2005; Caramaschi et al., 2007). These data raise the possibility that autoregulatory mechanisms obscure a simple linear relationship between aggression and serotonin neuron firing and/or neurotransmission.

Here, we tested the hypothesis that decreased serotonin activity is sufficient to increase aggression and whether decreased serotonin activity during development can modulate aggression in adulthood. We used two different cell-type specific pharmacogenetic tools in transgenic mice to selectively reduce serotonin activity either chronically or acutely and then tested for aggressive behavior in the resident intruder test. First, we used conditional overexpression of Htrla autoreceptors to chronically decrease 
A
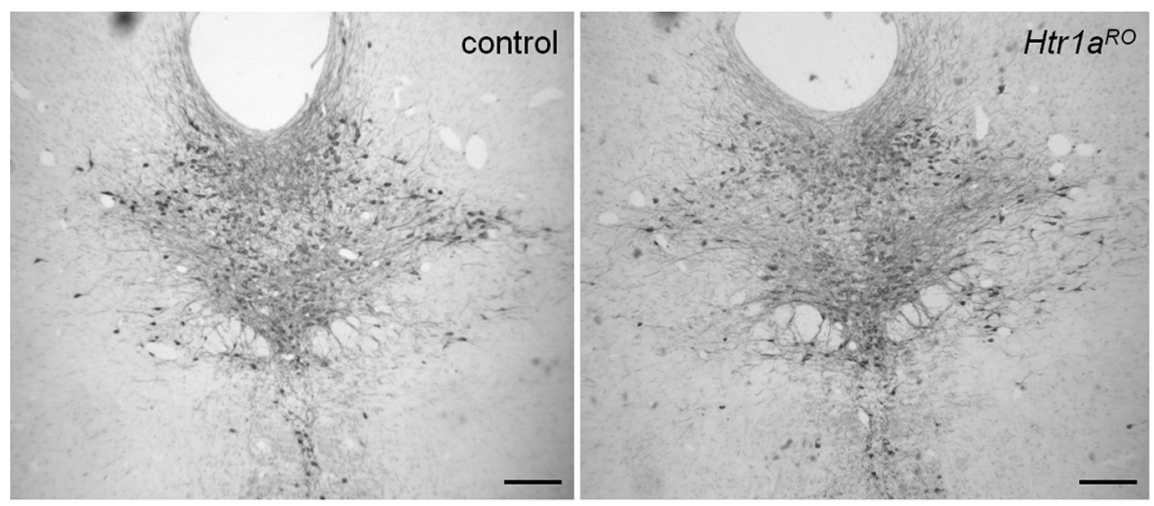

B

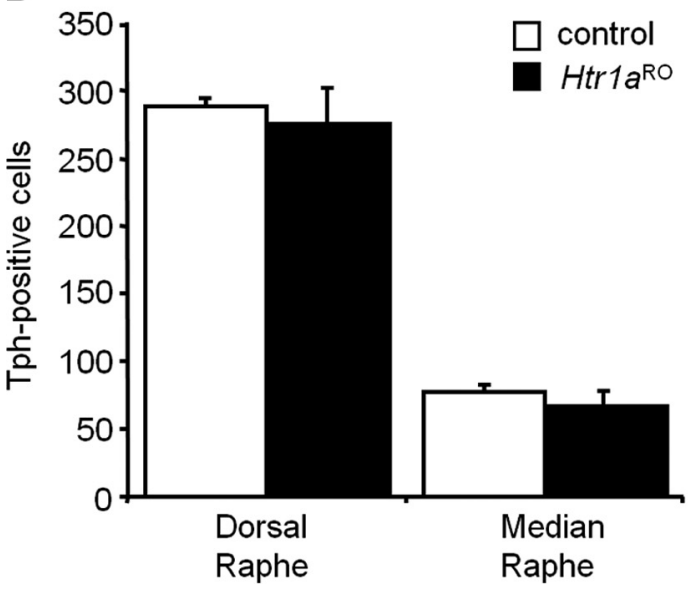

Figure 1. Normal number of serotonin neurons in $H \operatorname{tr} 1 a^{\mathrm{RO}}$ mice. $\boldsymbol{A}$, Representative images of brain sections containing the dorsal raphe nucleus taken from $H \operatorname{tr} 1 a^{\mathrm{RO}}$ and control littermates stained with anti-Tph antibodies. $\boldsymbol{B}$, No significant effect of genotype on total number of Tph-positive cells in dorsal and median raphe was observed (mean $\pm S E M, N=4$ ). Scale bars, $200 \mu \mathrm{m}$.

serotonin activity either during development or in adulthood. Second, we treated mice engineered to express Htrla only in serotonin neurons with an Htrla agonist to acutely reduce serotonin neuron firing. Our data demonstrate that a reduction of serotonin neuron activity during adulthood, but not during development, is sufficient to increase aggression, consistent with the low serotonin/high aggression hypothesis.

\section{Materials and Methods}

Transgenic mice. Slc6a $4^{\mathrm{tTA}}$ mice (EM:04891) were produced by replacing portions of exon 2 of the serotonin transporter gene starting at the initiating ATG with the coding sequence of the tetracycline transactivator protein (tTA) followed by bGH polyA sequences and an FRT-flanked neomycin resistance cassette using gene targeting in W9.5 ES cells as previously described (Audero et al., 2008). Htrla ${ }^{\text {tetO }}$ mice were produced by removing the loxP-flanked neomycin resistance transcriptional stop cassette from Htrla ${ }^{S T O P-t e t O}$ knock-out mice (Gross et al., 2002) as previously described (Audero et al., 2008). The Htrla ${ }^{\text {tetO }}$ allele carries a tetO-CMV promoter targeted to the $5^{\prime}$-UTR of the endogenous Htrla gene that mediates tTA-dependent overexpression of the receptor. $H \operatorname{tr} 1 a^{\mathrm{RO}}$ and control littermates were produced by breeding $+/+; \mathrm{Htrla}^{\text {teto } /}$ $H$ trla $a^{\text {tetO }}$ and Slc $6 a 4^{\mathrm{tTA}} /+; H$ tr $1 a^{\text {tetO }} / H$ trl $a^{\text {tetO }}$ mice. All mice were maintained on a 129S6/SvEvTac;C57BL/6;CBA background and were derived from the same breeding colony as mice used in the study by Audero et al. (2008). The $H \operatorname{trl} a^{\mathrm{RR}}$ line was produced by crossing a line carrying a Tph2Htrla transgene with $\mathrm{Htrla}^{\mathrm{KO}}$ mice (Ramboz et al., 1998). Tph2-Htrla mice were produced by pronuclear injection in [C57BL/6JxCBA/J]xC57BL/6J embryos of a circular mouse BAC (RP23112F24; Chori-BACPAC Resources) containing $220 \mathrm{~kb}$ of the Tph 2 gene in which Htrla coding sequences followed by a bovine growth hormone polyadenylation sequence and an FRT-flanked kanamycin resistance marker (FLP deleted in bacteria before DNA injection) had been inserted at the start codon of the Tph 2 gene. Founders carrying the transgene were identified and genotyped by PCR, crossed to Htrla ${ }^{\mathrm{KO}}$ mice, and maintained on a mixed C57BL/6J;CBA/J;129S6/ SvEvTac background. Expression levels in two independent founder lines ( $\operatorname{Tg} 10$ and $\operatorname{Tg} 24)$ were similar and a mixture of the two lines was used for all behavioral experiments. $H \operatorname{trl} a^{\mathrm{RR}}$ and control littermates were produced by breeding $+/+; H \operatorname{trl} a^{\mathrm{KO}} / \mathrm{Htrla} \mathrm{KO}^{\mathrm{KO}}$ and Tph2-Htr1a/+; Htr $1 a^{\mathrm{KO}} / \mathrm{Htr} 1 a^{\mathrm{KO}}$ mice.

Animal husbandry. Mice were group housed (3-5/cage) on a 12/12 h light/dark cycle (lights off at 7:00 P.M.) in a temperature-controlled environment $\left(21 \pm 0.5^{\circ} \mathrm{C}\right)$. Food and water were provided ad libitum. Doxycycline was given to the animals or pregnant mothers in the form of food pellets ( $40 \mathrm{mg} / \mathrm{kg}$ food; Bio-Serv).

Immunohistochemistry. Animals were deeply anesthetized by injection of $25 \%$ avertin (Sigma-Aldrich) and transcardially perfused with $4 \%$ paraformaldehyde (PFA, SigmaAldrich). Brains were removed from the skull, postfixed with 4\% PFA in PBS and cryoprotected in $30 \%$ sucrose. Coronal sections (12 $\mu \mathrm{m})$ were cut in a cryostat and mounted on glass slides (Superfrost Plus, Thermo Scientific). Sections were allowed to dry at room temperature and incubated in $10 \mathrm{~mm}$ citrate buffer $\mathrm{pH} 6.0$ containing $0.05 \%$ Tween at $96^{\circ} \mathrm{C}$ for $10 \mathrm{~min}$ to allow unmasking of the epitope. After blocking endogenous peroxidase activity for 30 min with $0.6 \% \mathrm{H}_{2} \mathrm{O}_{2}$ in TBS (Trisbuffered saline), sections were preincubated for $1 \mathrm{~h}$ at room temperature in blocking solution containing $5 \%$ fetal bovine serum, $2 \%$ BSA (bovine serum albumine) and $0.25 \%$ Triton X-100 diluted in TBS. Sections were then incubated in mouse monoclonal anti-Tph antibody (1:400, SigmaAldrich) overnight at $4^{\circ} \mathrm{C}$. Detection was performed with biotinylated secondary antibodies (horse anti-mouse IgG, 1:300; Vector Laboratories) diluted in blocking solution for $90 \mathrm{~min}$, followed by incubation in streptavidin-biotin-peroxidase complex (Vector Laboratories) for $1 \mathrm{~h}$ at room temperature. Peroxidase activity was visualized using diaminobenzidine substrate (Sigma-Aldrich) for $10 \mathrm{~min}$ at room temperature. Sections were dehydrated in ethanol and mounted in mounting medium (Eukitt, Sigma-Aldrich). Quantification was performed by counting Tph-positive neurons in dorsal and median raphe in every third section.

Behavioral testing. Procedures were performed according to Italian guidelines for ethical animal treatment following protocols authorized by the Italian Ministry of Health. Mice were transferred to the phenotyping facility 1 week before testing. Each behavioral test was performed on independent cohorts of $8-10$-week-old animals. Illumination of the testing rooms was 150 Lux.

Open field. Mice were habituated to the testing room for $60 \mathrm{~min}$ before being placed into a gray plastic arena $(50 \times 50 \mathrm{~cm})$ for $60 \mathrm{~min}$. Locomotion data were collected by a video tracking system (TSE Systems). Animals were initially placed along one side of the arena, and the center region was defined as the central $26 \times 26 \mathrm{~cm}$ area.

Elevated-plus maze. Mice were habituated to the room for $10 \mathrm{~min}$ before been placed into the central platform $(5 \times 5 \mathrm{~cm})$ of a gray plastic maze facing toward an open arm (open arms, $30 \times 5 \mathrm{~cm}$, surrounded by a $0.25 \mathrm{~cm}$ high border; closed arms, $30 \times 5 \mathrm{~cm}$, surrounded by $15 \mathrm{~cm}$ high 
walls). The entire apparatus was elevated $45 \mathrm{~cm}$ above the floor. Locomotion data were collected for $5 \mathrm{~min}$ by a video tracking system (TSE Systems).

Resident-intruder assay. For isolationinduced aggression, male resident mice were isolated for at least 4 weeks before the first resident-intruder test and maintained isolated throughout testing. Aggressive behavior was monitored during 15 min exposure to unique wild-type C57BL/6J intruder mice that had been group-housed (5/cage). Three test trials were conducted, one trial per week. The latency to first biting attack, total number of biting attacks, and time spent ano-genital sniffing, crawling over, and social grooming were scored from videotape. A latency time of $900 \mathrm{~s}$ was assigned to the animals that did not display any attacks during the test. The Htrla agonist 8-OH-DPAT (8-hydroxy- $N$-[di- $n$-propyl]aminotetralin; Sigma-Aldrich) and Htrla antagonist WAY100635 (Sigma-Aldrich) were dissolved in $0.9 \%$ saline and injected subcutaneously $30 \mathrm{~min}$ before the third trial.

Receptor autoradiography. Brains were removed, frozen in dry ice, and stored at $-80^{\circ} \mathrm{C}$ before sectioning. Coronal sections $(16 \mu \mathrm{m})$ were cut in a cryostat, preincubated in binding buffer (50 mm Tris- $\mathrm{HCl} \mathrm{pH} 7.4,2 \mathrm{~mm} \mathrm{MgCl}_{2}$ ) for $30 \mathrm{~min}$ before incubation in binding buffer containing $0.14 \mathrm{~nm}{ }^{125} \mathrm{I}$-MPPI (Kung et al., 1995) (kindly provided by Karl Ploessl and Hank Kung, Department of Radiology, University of Pennsylvania, PA) for $60 \mathrm{~min}$. Sections were washed in ice-cold binding buffer $(2 \times 10 \mathrm{~min})$, rinsed in distilled water, and air-dried. Slides were exposed to single-sided Kodak BioMax film (Kodak) for 2-4 d.

Hypothermia. Animals were singly housed the day before testing. 8-OH-DPAT was dissolved in $0.9 \%$ saline and injected subcutaneously at a concentration of $0.5 \mathrm{mg} / \mathrm{kg}$ body weight. Control animals were treated with $0.9 \%$ saline in equivalent volumes. Body temperature was recorded in 10 min intervals with a digital rectal thermometer (Bioseb).

Electrophysiology. Mice (P24-P60) were anesthetized with isofluorane and decapitated. The brain was rapidly removed, dissected in ice-cold gassed $\left(95 \% \mathrm{O}_{2}\right.$ and $5 \% \mathrm{CO}_{2}$ ) ACSF (artificial CSF) composed of: 124 mм NaCl, 2.75 mм KCl, $1.25 \mathrm{~mm} \mathrm{NaH}_{2} \mathrm{PO}_{4}, 1.3 \mathrm{~mm} \mathrm{MgCl}_{2}, 2 \mathrm{~mm} \mathrm{CaCl}{ }_{2}$, $26 \mathrm{~mm} \mathrm{NaHCO}, 11 \mathrm{~mm}$ D-glucose, and the brainstem sliced coronally into 250- $\mu$ m-thick slices with a vibratome (DSK, T1000; Ted Pella, Inc.). After recovery for at least $2 \mathrm{~h}$ at room temperature, the slices were individually transferred into the recording chamber and perfused

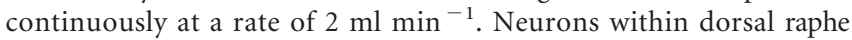
nucleus were visualized by infrared differential interference contrast video microscopy with a Newicon camera (C2400-07; Hamamatsu Photonics) mounted on an upright microscope (Axioskop; Zeiss). Recordings were made using an EPC-10 amplifier (HEKA Elektronic). Signals were filtered at $1-10 \mathrm{kHz}$ and digitized at $5-40 \mathrm{kHz}$. Data were analyzed using Fitmaster 2 (HEKA Elektronic) and Clampfit 9.2 (Molecular Devices). Patch pipettes (2-5 $\mathrm{M} \Omega$ resistance) were prepared from thick-walled borosilicate glass on a P-97 Brown-Flaming electrode puller (Sutter Instruments).

Whole-cell recordings. Whole-cell recordings were done on slices from $\mathrm{P} 24-\mathrm{P} 36$ mice on $28.5 \pm 0.5^{\circ} \mathrm{C}$. To block synaptic transmission, in all experiments extracellular solution consisted of oxygenated ACSF supplemented with $10 \mu \mathrm{M}$ NBQX (2,3-dioxo-6-nitro-1,2,3,4-tetrahydrobenzo[f] quinoxaline-7-sulfonamide disodium salt), $20 \mu \mathrm{M}$ D-APV (D-(-)-2amino-5-phosphonopentanoic acid), $10 \mu \mathrm{M}$ strychnine hydrochloride, 10 $\mu \mathrm{M}$ SR-95531 (6-imino-3-(4-methoxyphenyl)-1(6H)-pyridazinebutanoic acid hydrobromide), and $2 \mu \mathrm{M}$ CGP 55845A (3-N [1-( S)-(3,4-dichlorophenyl)ethyl]amino-2-( $S$ )-hydroxypropyl-P-benzyl-phosphinic acid). Pipette solution consisted of: $120 \mathrm{~mm}$ K Gluconate, $15 \mathrm{~mm} \mathrm{KCl}, 2 \mathrm{~mm} \mathrm{MgCl}$, $10 \mathrm{~mm}$
B
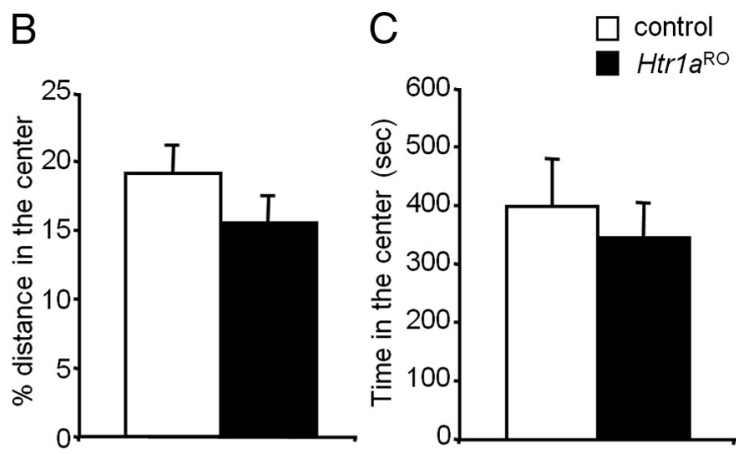

$\mathrm{E}$

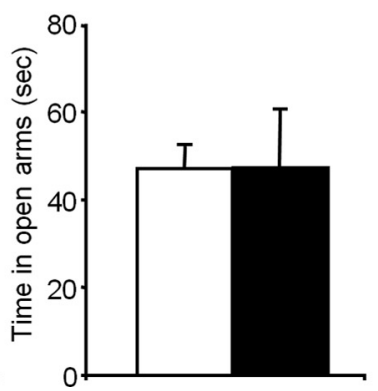

$\mathrm{F}$

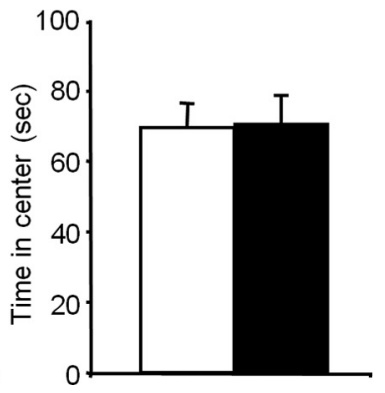

, 0.1 mu EGTA, 10 mm Na 2 Phosphocreatine, 4 mm MgATP, 0.3 mm $\mathrm{Na}_{3} \mathrm{GTP}$ ( $\mathrm{pH} 7.35$ with $\mathrm{KOH}$ ). Serotonergic and nonserotonergic neurons were classified according to existing electrophysiological criteria (Vandermaelen and Aghajanian, 1983; Li et al., 2001; de Kock et al., 2006). Serotonergic cells were identified on the basis of electrophysiological properties displayed in current-clamp mode after establishing whole-cell recording configuration: action potential half-height width $>1.5 \mathrm{~ms}$; absence of fast afterhyperpolarization; absence of depolarizing sag in response to hyperpolarizing pulse (from $-60 /-65$ to $-110 /-120 \mathrm{mV}$ ); maximal sustained firing rate $<12 \mathrm{~Hz}$ (in response to long depolarizing current pulses). Cells were considered nonserotonergic when they had action potential half-height width $<1.2 \mathrm{~ms}$; fast afterhyperpolarization; depolarizing sag; maximal sustained firing rate $>20 \mathrm{~Hz}$. If neurons displayed intermediate electrophysiological properties ( $<15 \%$ of cells) the recording was aborted. All included neurons had action potential height (peak-to-peak) $>100 \mathrm{mV}$. The access resistance ranged from 5-18 M $\Omega$ and was not compensated. Recordings were terminated if it changed $>15 \%$. Current-voltage relationships were obtained by averaging 5-7 single responses to hyperpolarizing ramps (from -65 to $-130 \mathrm{mV}, 100 \mathrm{mV} \mathrm{s}^{-1}$ ).

Loose-seal cell-attached recordings. Loose cell-attached recordings were done on slices from P30-P60 mice on $34.5 \pm 0.5^{\circ} \mathrm{C}$. To facilitate firing, extracellular saline, otherwise the same as in whole-cell recordings, was supplemented with the $10 \mu \mathrm{M}$ phenylephrine (Baraban and Aghajanian, 1980; Vandermaelen and Aghajanian, 1983). Pipette solution contained the following: $125 \mathrm{~mm} \mathrm{NaCl}, 10 \mathrm{~mm}$ HEPES, $2.75 \mathrm{~mm} \mathrm{KCl,} 2 \mathrm{~mm} \mathrm{CaCl}_{2}$, $1.3 \mathrm{~mm} \mathrm{MgCl}_{2}$ (pH 7.4 with $\mathrm{NaOH}$ ). Pipette potential was set at $0 \mathrm{mV}$ in voltage-clamp mode. Recordings were aborted if firing frequency was sensitive to changes in pipette holding potential or if shape of action current changed. Neurons were identified according to electrophysiological criteria (Vandermaelen and Aghajanian, 1983; Allers and Sharp, 2003). Neurons were considered serotonergic if they displayed slow and steady firing rate $(1-4 \mathrm{~Hz}$ with $\mathrm{COV}<15 \%)$, and asymmetric action current (ratio of upstroke to downstroke $>3.5$ ) with long peak-to-peak interval ( $>1.2 \mathrm{~ms}$, proportional to action potential half-height width) during at least a 5-min-long control period at the beginning of the recording. Nonserotonergic cells fired either irregularly $(\mathrm{COV}>30 \%)$ or 
fast and regularly (firing rate $>6 \mathrm{~Hz}$ ) and showed more symmetric action current with shorter peak-to-peak interval $(<0.9 \mathrm{~ms})$ than serotonergic neurons. For experiments that depended on endogenous serotonin, i.e., with tryptophan application, recordings were done from neurons located at least $50 \mu \mathrm{m}$ below the slice surface (Mlinar et al., 2005). In experiments in which single agonist concentration was applied, steady-state values were calculated as average firing rate over the last $3 \mathrm{~min}$ of the application, while in concentration-response experiments, values correspond to the last minute of the application.

Statistical analysis. Statistical analysis was performed using StatView (version 5.0, SAS Institute) and Prism 4 (GraphPad Software). Unless otherwise indicated, the effects of genotype or treatment on dependent variables were analyzed by ANOVA using repeated measures where indicated, followed by unpaired Student's $t$ test in case of significance. Chi-squared testing was used to assess the effect of genotype on the proportion of mice attacking. For the pharmacological challenge tests, data were not normally distributed and nonparametric analysis was performed using paired Wilcoxon matched pairs test.

\section{Results}

\section{Heightened aggression in mice with chronic decrease in serotonin activity}

To examine the behavioral consequences of a chronic reduction in serotonin neuron firing we used a double transgenic mouse line in which negative feedback inhibition of serotonin neurons was enhanced by the selective overexpression of the Htrla autoreceptor (Audero et al., 2008). Tissue-specific conditional overexpression of Htrla autoreceptor was obtained using the tet-OFF system. Mice carrying the tetracycline transactivator (tTA) gene under control of the endogenous serotonin transporter promoter (called Slc6a $4^{\mathrm{tTA}}$ ) were crossed to mice carrying a tTA-inducible allele of the endogenous Htrla gene (called Htrla ${ }^{\text {tetO }}$ ) (Fig. 1A). Double transgenic mice (called Htrla raphe overexpressing, or $H \operatorname{tr} 1 a^{R O}$ ) showed Htrla protein overexpression exclusively in raphe nuclei of the mid- and hindbrain and electrophysiological studies in slices taken from these animals revealed decreased serotonin neuron firing in the presence of the serotonin precursor tryptophan (Audero et al., 2008). Neurochemical analysis of whole brain tissue samples confirmed reduced serotonin turnover (ratio of 5-HIAA to 5-HT) consistent with decreased steady-state serotonin neuron activity (Audero et al., 2008). Importantly, $H \operatorname{tr} 1 a^{\mathrm{RO}}$ mice showed no change in the number of Tphimmunoreactive cell bodies in dorsal and median raphe nuclei (Fig. 1 $A, B$ ), demonstrating that increased serotonin autoinhibition does not interfere with the proliferation or maintenance of serotonin neurons.

To assess the consequences of chronically reduced serotonin activity on anxiety-like and aggressive behavior, we tested $H \operatorname{tr} 1 \mathrm{a}^{\mathrm{RO}}$ and control littermates in the open field, elevated plus maze, and resident-intruder tests. Htr $1 a^{\mathrm{RO}}$ mice showed normal levels of total locomotion (ANOVA: $F_{(1,21)}=0.086, p=0.772$ ), percentage distance in center (ANOVA: $F_{(1,21)}=1.445, p=0.242$ ), and time in center (ANOVA: $F_{(1,21)}=0.237, p=0.631$ ) in the open field (Fig. $2 A-C$ ) and time in closed arms (ANOVA: $F_{(1,25)}=3.65 \mathrm{E}-6, p=$ 0.998 ), time in open arms (ANOVA: $F_{(1,25)}=0.002, p=0.963$ ), and time in center platform (ANOVA: $F_{(1,25)}=0.017, p=0.898$ ) in the elevated-plus maze tests (Fig. $2 D-F$ ), suggesting normal reactivity to a novel aversive environment. No interaction between sex and genotype was observed [OF total locomotion (ANOVA genotype $\times$ sex: $\left.F_{(1,21)}=1429, p=0.2427\right)$, OF percentage distance in center (ANOVA genotype $\times$ sex: $\left.F_{(1,21)}=1611, p=0.156\right)$, OF time in the center (ANOVA genotype $\times$ sex: $\left.F_{(1,21)}=1095, p=0.3050\right), \mathrm{EPM}$ time in closed arms (ANOVA genotype $\times$ sex: $F_{(1,25)}=0127, p=$ 0.723 ), EPM time in open arms (ANOVA genotype $\times$ sex: $F_{(1,25)}=$
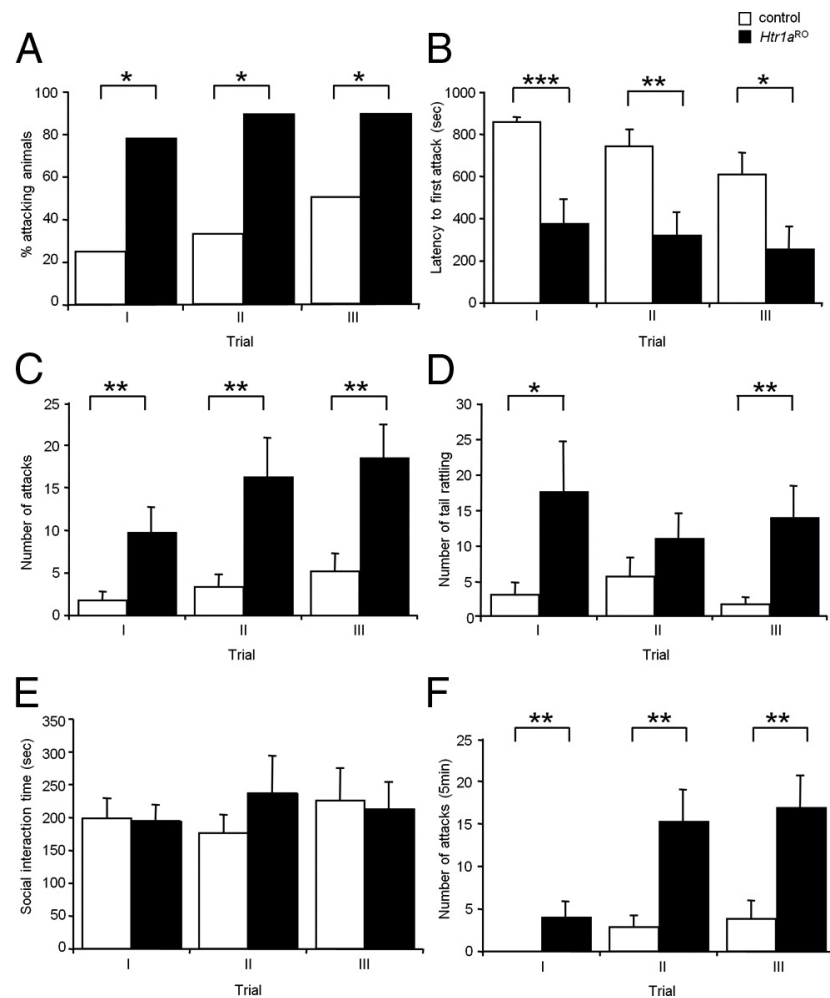

$\mathrm{F}$

Figure 3. Increased aggression in $\mathrm{Htr} 1 a^{\mathrm{RO}}$ mice. Male mice were isolated for 4 weeks before testing during three trials of the resident-intruder assay at one-week intervals starting at P60. $\boldsymbol{A}$, The proportion of $\mathrm{Htr} 1 a^{\mathrm{R} 0}$ mice attacking an intruder was significantly higher compared with controls. $\boldsymbol{B}-\boldsymbol{D}, H \operatorname{tr} 1 a^{\mathrm{RO}}$ mice showed a significant decrease in latency to the first attack $(\boldsymbol{B})$, increase in total number of attacks $(\boldsymbol{C})$, increase in tail rattling episodes $(\boldsymbol{D})$, but no difference in total social interaction time ( $\boldsymbol{E}$; ano-genital sniffing, crawling over, and social grooming) during each of the three trials when compared with control littermates. $H \operatorname{tr} 1 a^{\mathrm{RO}}$ mice also showed a significantly increased number of attacks during the 5 min following the first biting attack ( $\boldsymbol{F}$; controls: $\left.N=9, H \operatorname{tr} 1 a^{\mathrm{RO}}: N=12 ;{ }^{*} p<0.05,{ }^{* *} p<0.01,{ }^{* * *} p<0.001\right)$.

$0143, p=0.143$ ), and EPM time in center platform (ANOVA genotype $\times$ sex: $\left.\left.F_{(1,25)}=0005, p=0.941\right)\right]$.

We examined aggressive behavior in $H_{t r 1} a^{\mathrm{RO}}$ mice in a standard resident-intruder assay of isolation-induced intermale aggression (Schneider et al., 1992; Saudou et al., 1994; Hendricks et al., 2003). In this assay, an unfamiliar male intruder is placed in the home cage of a singly housed resident test mouse. Display of territorial aggression is measured by counting the number of attacks and tail rattling episodes of the resident mouse and the latency to the first attack. Under these conditions, the proportion of control mice attacking a conspecific intruder (Fig. $3 A$ ) and the total number of attacks (Fig. $3 C$ ) increased and the latency to attack (Fig. 3B) decreased across trials, demonstrating a sensitization of aggressive behavior over time. The proportion of male Htrla ${ }^{\mathrm{RO}}$ mice attacking an intruder was significantly higher compared with control littermates $\left(\chi^{2}\right.$ test, trial I $p=0.0166$; trial II $p=0.0109$; trial III $p=0.0121$; Fig. 3A). Male Htr $1 a^{\mathrm{RO}}$ mice showed a significant reduction in the latency to attack (repeated measure ANOVA - main effect of genotype: $F_{(19,38)}=16.11, p=$ 0.0007; main effect of trial: $F_{(19,38)}=3.48, p=0.041$; trial $\times$ genotype interaction: $\left.F_{(19,38)}=0.42, p=0.662\right)$ and increase in the number of attacks (repeated measure ANOVA-main effect of genotype: $F_{(19,38)}=15.80, p=0.0008$; main effect of trial: $F_{(19,38)}=4.32, p=0.020$; trial $\times$ genotype interaction: $F_{(19,38)}=$ $1.04, p=0.362$ ) and tail rattling episodes (repeated measure ANOVA-main effect of genotype: $F_{(19,38)}=6.917, p=0.0165$; 
main effect of trial: $F_{(19,38)}=0.68, p=$ 0.770 ; trial $\times$ genotype interaction: $\left.F_{(19,38)}=1.56, p=0.222\right)$ over all three sessions when compared with control littermates (Fig. $3 B-D$ ). The time spent in ano-genital sniffing, crawling over, and social grooming with the intruder did not differ between Htrla ${ }^{\mathrm{RO}}$ mice and control littermates (repeated measure ANOVAmain effect of genotype: $F_{(19,38)}=0.138$, $p=0.714$; main effect of trial: $F_{(19,38)}=$ $0.34, p=0.713$; trial $\times$ genotype interaction: $F_{(19,38)}=0.81, p=0.450$; Fig. $3 E$ ). An increased number of attacks and tail rattling episodes could be simply a consequence of the shorter attack latency in Htrla ${ }^{\mathrm{RO}}$ animals. However, the number of attacks occurring during the $5 \mathrm{~min}$ following the first biting attack were also significantly increased in $\mathrm{Htrla}^{\mathrm{RO}}$ animals compared with controls (repeated measure ANOVA - main effect of genotype: $F_{(19,38)}=16.78, p=0.0006$; Fig. $\left.3 F\right)$. Differences in frequency of attacks and tail rattling between Htrla ${ }^{\mathrm{RO}}$ mice and control littermates were also evident in plots of attacks and tail rattling events across individual mice (Fig. 4A,B). These data demonstrate that long-term reductions in serotonin activity are associated with heightened aggression in the absence of changes in anxiety or motivation for social interaction. In addition, these differences do not appear to be the result of altered learning or escalation of violence as similar differences were seen on the first and subsequent testing days.

\section{Heightened aggression is not developmentally programmed}

To test whether the increased aggression seen in $H$ trla ${ }^{\mathrm{RO}}$ mice was due to reduced serotonin activity during development, adulthood, or both, we turned on and off the receptor by treating $H \operatorname{tr} 1 a^{\mathrm{RO}}$ mice during different periods of life with doxycycline. Doxycycline blocks the binding of tTA protein to its target tetO sequence and can be used to prevent or reverse overexpression of Htrla in Htrla ${ }^{\mathrm{RO}}$ mice (Audero et al., 2008). Suppression of Htrla overexpression during development was achieved by doxycycline treatment of mothers and their Htrla ${ }^{\mathrm{RO}}$ and control littermate offspring until postnatal day 40 (P40; Fig. $5 A)$. When tested in the resident-intruder test at P60, Htrla $a^{\mathrm{RO}}$ mice treated during development with doxycycline showed a significant decrease in latency to attack (repeated measure ANOVA-main effect of genotype: $F_{(17,34)}=11.633, p=$ 0.0033 ) and increase in number of attacks (repeated measure ANOVA - main effect of genotype: $F_{(17,34)}=10.627, p=$ $0.0046)$ toward the intruder when compared with control animals. Similar heightened aggression was seen on the first and subsequent encounters (Fig. $5 B, C$ ). Again, no effect of genotype was seen on time spent in social interaction (repeated measure
ANOVA-main effect of genotype: $F_{(17,34)}=0.21, p=0.6523$, Fig. 5D), suggesting that adult overexpression of Htr1a was sufficient to explain the heightened aggression seen in untreated Htrla ${ }^{\mathrm{RO}}$ mice (Fig. 3). On the other hand, when Htrla $a^{\mathrm{RO}}$ and control littermates were treated with doxycycline beginning at P21 and tested at P60 (Fig. 5E), no significant effect of genotype on latency to attack (repeated measure ANOVA-main effect of genotype: $\left.F_{(13,26)}=1.406, p=0.2569\right)$, number of attacks (repeated measure ANOVA-main effect of genotype: $F_{(13,26)}=0.025, p=$ 0.8763 ), or time spent in social interaction (repeated measure ANOVA-main effect of genotype: $\left.F_{(13,26)}=3.286, p=0.0903\right)$ was seen (Fig. $5 F-H$ ). Together, these data demonstrate that chronic suppression of serotonin activity during adulthood, but not development, was sufficient to cause increased aggression. 
A
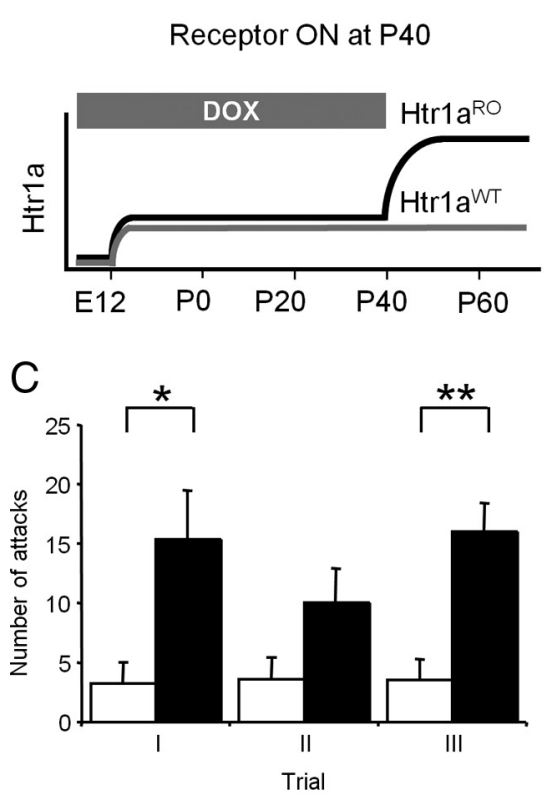

$E$

Receptor OFF at P21

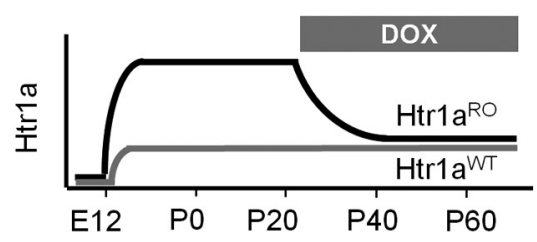

G

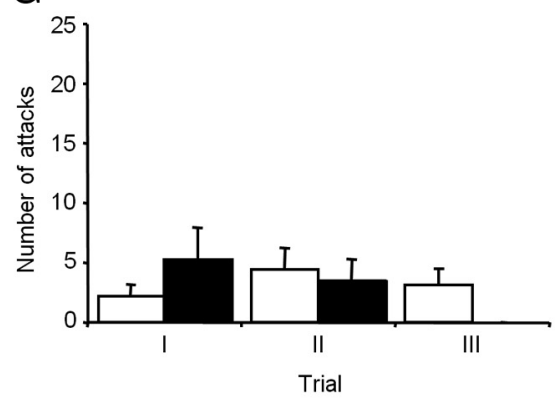

$\mathrm{H}$

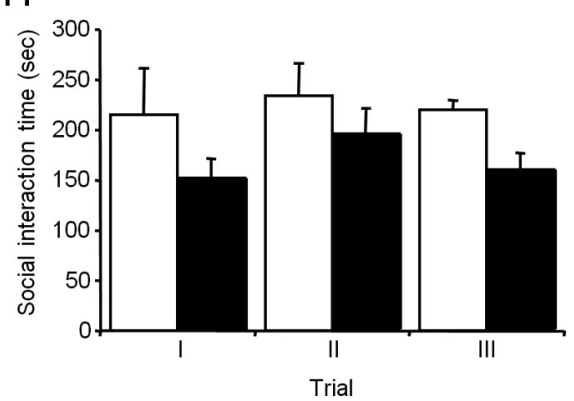

Figure 5. Increased aggression in $\mathrm{Htr} 1 a^{\mathrm{R} 0}$ mice overexpressing Htrla in adulthood. $\mathrm{A}, \mathrm{Htr} 1 a^{\mathrm{R} 0}$ and control littermates were treated until P40 with doxycycline to block overexpression of Htr1a during development and tested during three trials of the resident intruder assay at one-week intervals starting at $\mathrm{P} 60 . \mathbf{B}-\boldsymbol{D}, \mathrm{Htr} 1 a^{\mathrm{RO}}$ mice showed a significant decrease in latency to the first attack $(\boldsymbol{B})$, increase in total number of attacks $(\boldsymbol{C})$, but no difference in total social interaction time ( $\boldsymbol{D}$; ano-genital sniffing, crawling over, and social grooming) when compared with control littermates (controls: $\left.N=10, \operatorname{Htr}^{\mathrm{RO}}: N=9\right) . \boldsymbol{E}, \operatorname{Htr}^{\mathrm{R}} \mathrm{a}^{\mathrm{RO}}$ and control littermates were treated from P21 with doxycycline to block overexpression of Htr1a during adulthood and tested during three trials of the resident intruder assay at one-week intervals starting at P60. $\boldsymbol{F}-\boldsymbol{H}, \mathrm{Htr} 1 a^{\mathrm{RO}}$ mice showed no significant differences in latency to the first attack $(\boldsymbol{F})$, total number of attacks $(\boldsymbol{G})$, or total social interaction time $(\boldsymbol{H}$; ano-genital sniffing, crawling over, and social grooming) when compared with control littermates with the exception of the last trial where $\mathrm{Htr}^{\mathrm{a}}{ }^{\mathrm{RO}}$ animals showed a significant decrease in social interaction behavior (controls: $N=7, \operatorname{Htr}^{\mathrm{RO}}: N=8 ;{ }^{*} p<0.05,{ }^{* *} p<0.01$ ).

\section{Pharmacogenetic tool for the rapid suppression of serotonin activity}

Next, we investigated whether the increased aggression associated with the chronic suppression of serotonin activity would also be seen following rapid, acute inhibition of serotonin neuron firing. Because of its relatively slow kinetics (Kistner et al., 1996), the tet-OFF system does not lend itself to rapid manipulations of gene expression. To facilitate the rapid suppression of serotonin neuron firing, we treated mice in which Htrla was exclusively expressed in serotonin neurons with the Htrla selective agonist 8-OH-DPAT (Tsetsenis et al., 2007). Exclusive expression of Htrla in serotonin neurons was achieved by crossing Htrla knock-out mice (Ramboz et al., 1998) to a transgenic line in which Htrla expression was driven by the tryptophan hydroxylase 2 (Tph2) promoter (called Htrla raphe rescue, or $\mathrm{Htrla}^{\mathrm{RR}}$ mice; Fig. 6A). Autoradiography with the Htrlaselective ligand, ${ }^{125} \mathrm{I}-\mathrm{MPPI}$, confirmed exclusive localization of Htrla in the raphe nuclei of $H$ trla ${ }^{\mathrm{RR}}$ mice (Fig. $6 B$ ). To confirm functional rescue of Htrla autoreceptor function in vivo, we measured hypothermic responses to systemic administration of 8-OH-DPAT (Martin et al., 1992). Htrla ${ }^{\mathrm{RR}}$ mice showed a significant hypothermic response to the agonist that was absent in $\mathrm{Htrla}^{\mathrm{KO}}$ littermates (ANOVA: $F_{(42,462)}=5.163, p=0.0283$; Fig. 6C,D).

Electrophysiological recordings made in brain slices containing the dorsal raphe nucleus taken from $H$ trla ${ }^{\mathrm{RR}}$ and $H$ trla ${ }^{\mathrm{KO}}$ littermates confirmed functional restoration of Htrla activity selectively in serotonin neurons. Bath application of the selective (8-OH-DPAT, $100 \mathrm{~nm}$ ) or semiselective, but high efficacy (5-CT, 300 nм) Htrla agonist during intracellular whole-cell recording caused significant membrane hyperpolarization (two-tailed paired $t$ test: $p=0.004$ and $p=0.012$, respectively) and an increase in conductance slope (two-tailed paired $t$ test: $p=$ 0.002 and $p=0.0183$, respectively) in dorsal raphe cells from $H$ trla $a^{\mathrm{RR}}$, but not $H \operatorname{trl} a^{\mathrm{KO}}$ littermates (Fig. $7 A-D$ ). Agonist effects were reversed by the selective Htrla antagonist, WAY100635 (50 nM). Similarly, application of high concentrations of 8-OH-DPAT (100 nM) and 5-CT (100 nM) suppressed spontaneous firing of serotonin, but not nonserotonin neurons (Fig. $7 E-H$ ). Full dose-response curves revealed an $\mathrm{EC}_{50}$ for agonistinduced suppression of firing in Htrla ${ }^{\mathrm{RR}}$ mice (4.18 nM, 95\% C.I. 3.18 $5.51 \mathrm{~nm})$ that was indistinguishable from wild-type mice (2.03 nM, 95\% C.I. 1.69-2.45 nM), suggesting complete rescue of autoreceptor function (Fig. 7I). Finally, treatment of dorsal raphe slices with the serotonin precursor tryptophan caused significant autoreceptor-mediated suppression of neuronal firing in wildtype and Htrla ${ }^{\mathrm{RR}}$ (two-tailed paired $t$ test: $p=0.026$ and $p=$ 

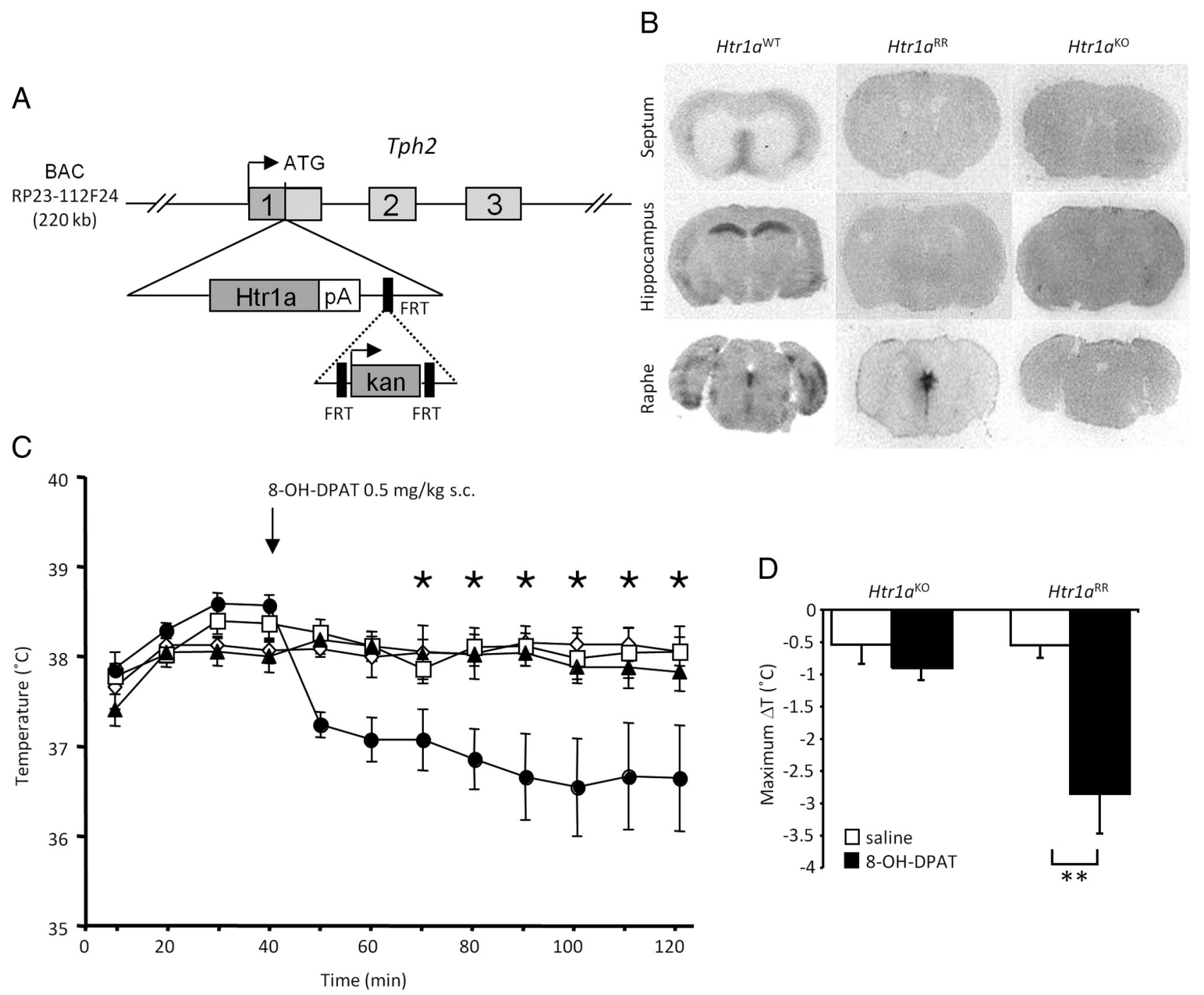

$$
\begin{array}{ll}
\diamond H \operatorname{tr} 1 a^{\mathrm{KO}}, \text { saline } & \mathbf{\Delta} H \operatorname{tr} 1 a^{R R} \text {, saline } \\
\square H \operatorname{tr} 1 a^{\mathrm{KO}}, 8-\mathrm{OH}-\mathrm{DPAT} & \bullet H \operatorname{tr} 1 a^{\mathrm{RR}}, 8-\mathrm{OH}-\mathrm{DPAT}
\end{array}
$$

Figure 6. Functional rescue of Htr1a autoreceptor. $A$, Schematic representation of Tph2-Htr1a transgene showing insertion of the Htr1a coding sequence at the start codon of the Tph2 gene in a mouse BAC. $\boldsymbol{B}$, Crossing of the Tph2-Htr1a transgene to $\mathrm{Htr} 1 a^{\mathrm{KO}}$ mice produced $\mathrm{Htr} 1 \mathrm{a}^{\mathrm{RR}}$ mice in which Htr1a expression as assessed by ${ }^{125} \mathrm{I}$-MPPI autoradiography was restricted to raphe nuclei. C, Htr 1a ${ }^{\mathrm{RR}}$ mice showed significant hypothermia in response to the Htr1a agonist 8-OH-DPAT (0.5 mg/kg, s.c.). Time course and maximum hypothermic response (D) following systemic administration of the Htr1a agonist or saline in $\mathrm{Htr} 1 a^{\mathrm{KO}}$ and $H \operatorname{tr} 1 a^{\mathrm{RR}}$ littermates $\left(N=8 ;{ }^{* *} p<0.01\right)$.

0.007, respectively), but not $\mathrm{Htrla}^{\mathrm{KO}}$ mice (Fig. $7 \mathrm{~J}, \mathrm{~K}$ ). Together, these data demonstrate functional rescue of Htrla selectively in serotonin neurons of $H \operatorname{trl} a^{\mathrm{RR}}$ mice.

\section{Acute suppression of serotonin neuron firing increases aggression}

To test whether acute reductions in serotonin neuron activity directly control aggressive behavior we examined the effect of treating $H \operatorname{trl} a^{\mathrm{RR}}$ mice with the Htrla agonist 8-OH-DPAT in the resident-intruder assay. Animals were subjected to two encounters with an intruder to measure baseline aggression and then, 30 min before the third trial, treated with either the Htrla agonist 8-OH-DPAT $(0.2 \mathrm{mg} / \mathrm{kg}$, s.c.) or antagonist WAY100635 (0.2 $\mathrm{mg} / \mathrm{kg}$, s.c.). A group of control animals was left untreated. Similar levels of aggression and social interaction were seen in all three groups in the first and second trials (Fig. $8 A-C$ ). During the third trial, however, agonist, but not control or antagonist treated resident mice showed a significant increase in the number of attacks toward the intruder when compared with the second trial (Wilconox matched pairs, trial II and III, $p=0.0076$, trial I and III, $p=0.0229$, trial I and II, $p=0.8927$ ) (Fig. $8 B$ ). However, only a trend for a decrease in latency to the first attack was seen in agonist treated mice when compared with control or antagonist treated mice on trial three (Fig. $8 A$ ), suggesting that acute suppression of serotonin firing primarily affects the persistence and/or recurrence of attacks rather than the timing of their initial occurrence. Again, changes in social interaction time did not explain the effect of agonist or antagonist treatment on aggression measures (ANOVA: $F_{(2,31)}=1.281, p=0.292$ ) (Fig. $8 C$ ). These data demonstrate that acute suppression of serotonin neuron firing is sufficient to promote heightened aggression.

\section{Discussion}

Our data demonstrate that chronic reductions in serotonin activity induced by overexpression of the Htrla autoreceptor were associated with a reduced latency to initiate and an increased 
A

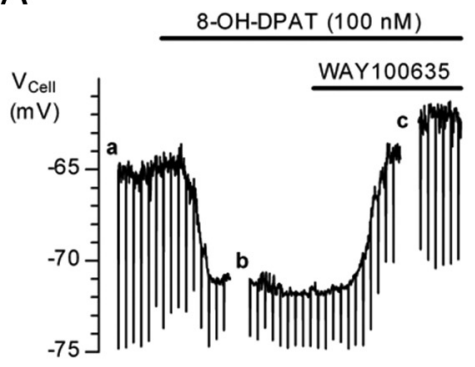

B

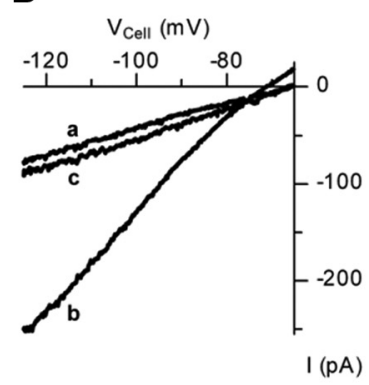

C

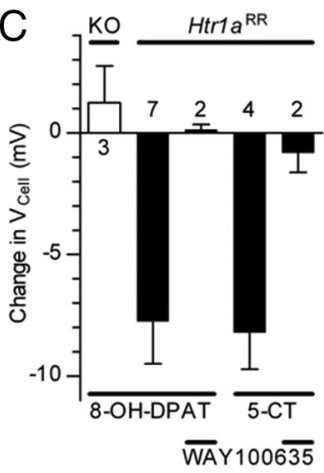

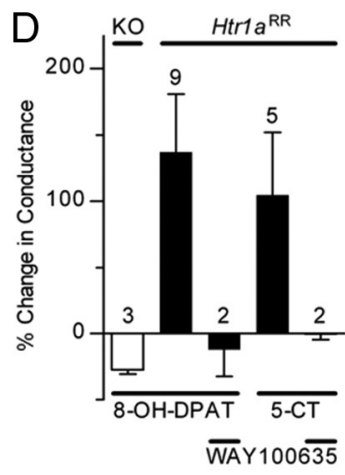

E

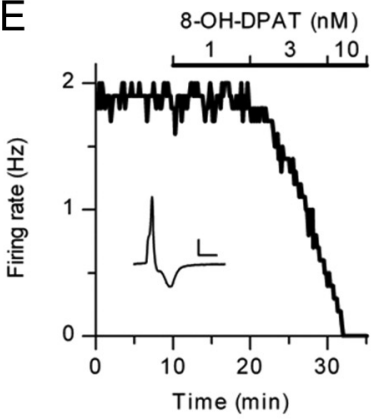

F

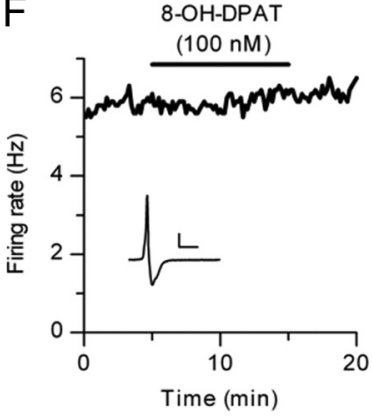

G

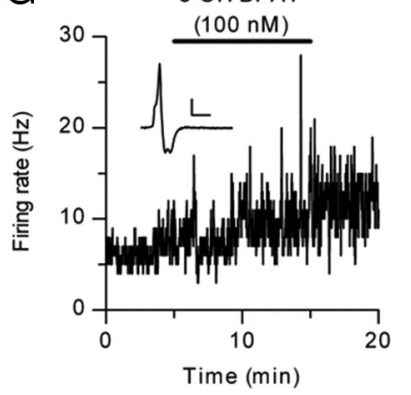

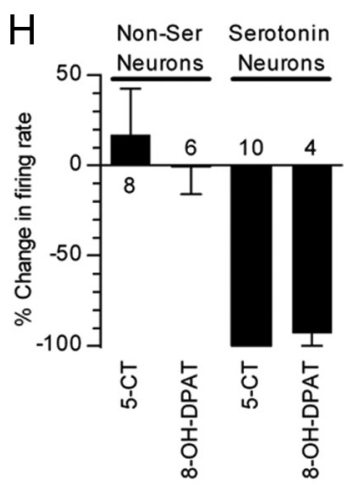
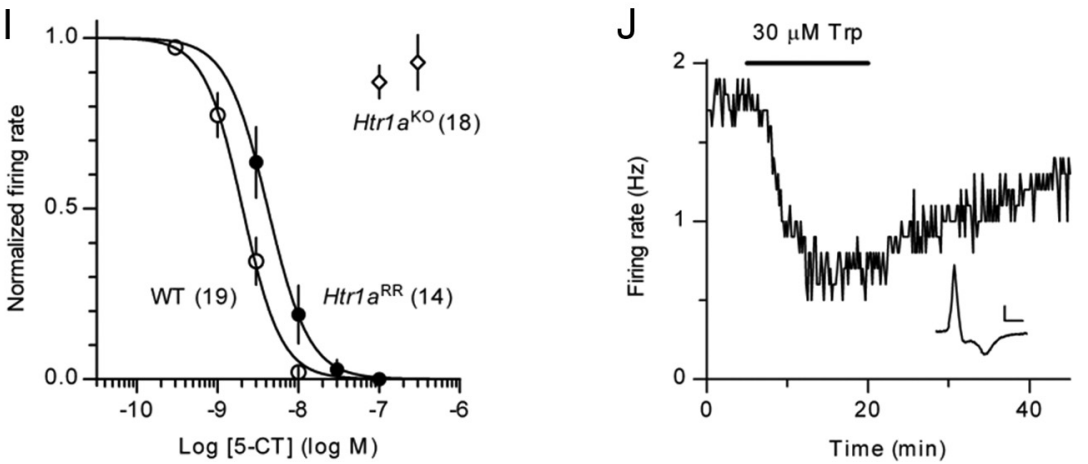

K

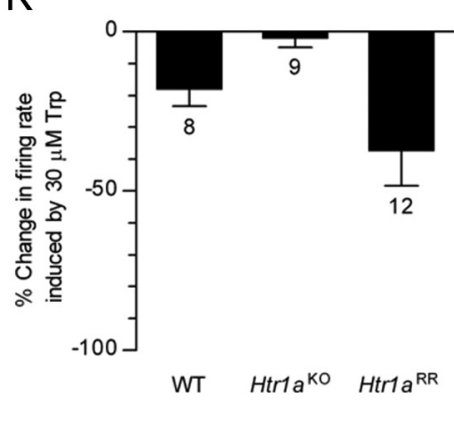

Figure 7. Electrophysiological characterization of $H$ tr1 $a^{\mathrm{RR}}$ mice. $\boldsymbol{A}-\boldsymbol{D}$, Whole-cell recordings. $\boldsymbol{A}$, Effect of the Htr1a agonist 8-OH-DPAT on the membrane potential of dorsal raphe nucleus serotonin neurons in $H \operatorname{tr} 1{ }^{R R}$ mice and its reversal by treatment with the Htr1a antagonist WAY100635 (50 nM). Downward deflections are responses to current pulses ( $-10 \mathrm{pA}$ ) used to monitor cell membrane resistance. $\boldsymbol{B}$, Current-voltage relationships at different time points ( $a-c)$ of cell shown in $\boldsymbol{A}$ obtained with hyperpolarizing ramps. $C$, Effect of 8-0H-DPAT (100 nM) and 5-CT (300 nM) on membrane potential ( $\left.\mathrm{V}_{\text {Cell }}\right)$ of cells from Htr $1 a^{\mathrm{KO}}(\mathrm{KO})$ and Htr1a ${ }^{\mathrm{RR}}$ mice and their reversal by WAY100635 (50 nM). Numbers indicate the number of cells in each group. D, Effect of 8-0H-DPAT (100 $\mathrm{nM}$ ) and $5-\mathrm{CT}\left(300 \mathrm{~nm}\right.$ ) on the slope conductance (between -120 and $-100 \mathrm{mV}$ ) determined from current-voltage ramps in cells from Htr $1 a^{\mathrm{KO}}$ and Htr1 ${ }^{\mathrm{RR}}$ mice and their reversal by WAY100635 $(50 \mathrm{~nm}) . \boldsymbol{E}-\boldsymbol{K}$, Loose-seal cell-attached recordings. Representative data of the suppression of firing of serotonin $(\boldsymbol{E})$, but not nonserotonin, constant frequency $(\boldsymbol{F})$ and nonserotonin, irregular frequency $(G)$ firing cells from $H$ tr $1 a^{R R}$ mice by treatment with increasing doses of 8-OH-DPAT. Action current waveforms used to distinguish serotonin from nonserotonin cells are shown in the insets (calibration: $\boldsymbol{E}, 1 \mathrm{~ms}, 100 \mathrm{pA} ; \boldsymbol{F}, 1 \mathrm{~ms}, 50 \mathrm{pA} ; \boldsymbol{G}: 1 \mathrm{~ms}, 20 \mathrm{pA}$ ). $\boldsymbol{H}$, Effect of single supramaximal concentration of 8-OH-DPAT (100 nM) and 5-CT (100 nm) on firing rate of serotonin and nonserotonin (Non-Ser) neurons. I, EC $\mathrm{E}_{50}$ curves for suppression of firing in dorsal raphe serotonin neurons in response to 5-CT showing wild-type control (WT) and functional recovery of Htr1a in Htr1a ${ }^{\mathrm{RR}}$. No response to 5 -CT was seen in $\mathrm{Htr}_{\mathrm{T}} \mathrm{a}^{\mathrm{K} 0}$ mice. Numbers indicate the total number of cells used for each genotype. $\boldsymbol{J}$, Representative and summary $(\boldsymbol{K})$ of data for the suppression of dorsal raphe serotonin neuron firing in wild-type control (WT), $H \operatorname{tr} 1 a^{\mathrm{RR}}$ (shown in $J$ ), but not $H \operatorname{tr} 1 a^{\mathrm{K} 0}$ mice following treatment with the serotonin precursor tryptophan (Trp). Inset shows action current waveform used to identify serotonin neurons (calibration: $1 \mathrm{~ms}, 25 \mathrm{pA}$ ).

number of attacks against an unfamiliar male intruder mouse. Overexpression of the Htrla autoreceptor during development was neither necessary nor sufficient to reproduce this heightened aggression phenotype arguing against a long-term effect of reduced serotonin activity on adult aggressive behavior. On the other hand, an acute reduction of serotonin activity in adult mice was sufficient to increase the number of attacks against an unfamiliar intruder, although it had only a moderate effect on reducing the latency to the initial attack. This finding is consistent with studies in the male tree shrew showing a transient reduction in serotonin neuron firing immediately before and during offensive, but not defensive antagonistic encounters (Walletschek and Raab, 1982). These findings argue that the firing of serotonin neurons directly modulates the timing and intensity of aggressive behavior toward threatening conspecifics and provide direct support for the low serotonin/high aggression hypothesis.

Several implications arise from our findings. First, our data support a direct causal relationship between low levels of the serotonin metabolite, 5-HIAA, and aggression-related behavior as has been postulated by associations between these measures 


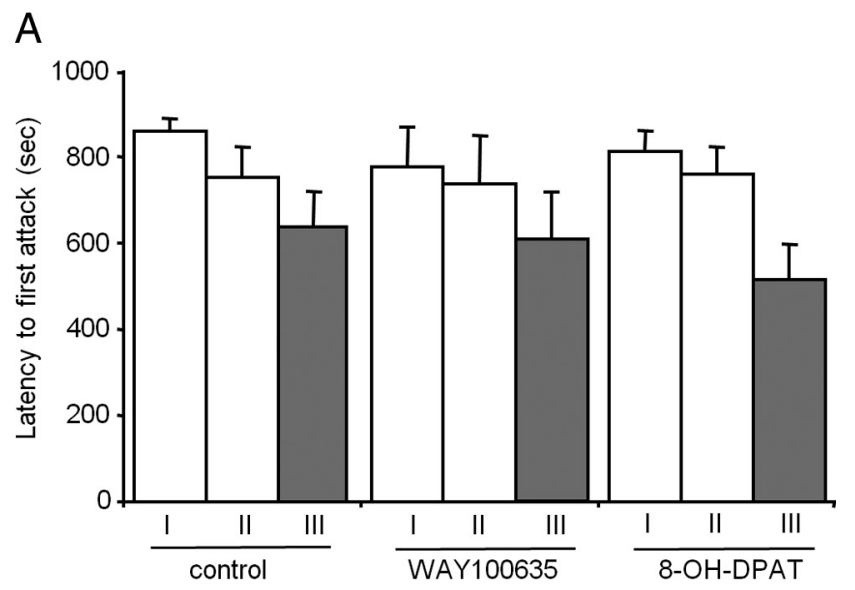

B

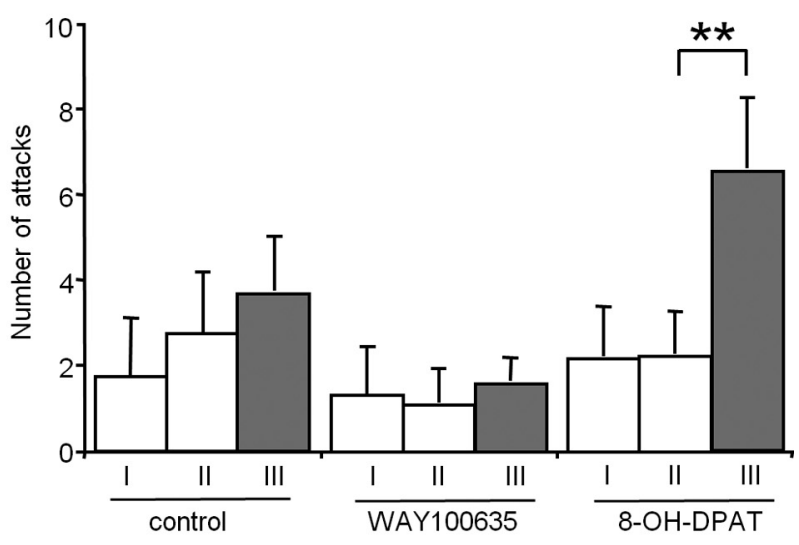

C

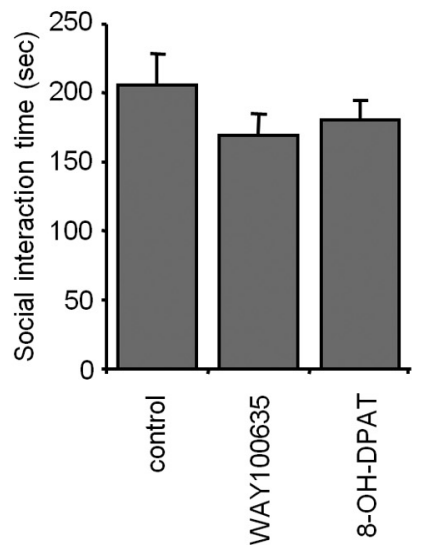

Figure 8. Increased aggression in Htr1 $a^{\mathrm{RR}}$ mice treated with 8-OH-DPAT. Three groups of male $\mathrm{Htr} 1 \mathrm{R}^{\mathrm{RR}}$ mice were isolated for 4 weeks before testing during three trials of the resident-intruder test starting at P60. Before testing on trial three, resident mice were injected with either the Htr1a agonist 8-OH-DPAT (0.2 mg $/ \mathrm{kg}$, s.C.) or antagonist WAY100635 $(0.2 \mathrm{mg} / \mathrm{kg}$, s.c.). A third group of mice received no injection (control). $\boldsymbol{A}, \boldsymbol{B}$, Treatment with 8-OH-DPAT caused a nonsignificant decrease in latency to first attack $(\boldsymbol{A})$ and a significant increase in total attacks $(\boldsymbol{B})$ toward the intruder when compared with behavior on the second trial or to behavior of WAY100635-treated mice. C, No significant difference in total social interaction time (ano-genital sniffing, crawling over, and social grooming) was observed between the three groups. Notably, no significant effect of WAY100635 was seen for any measure. No differences in behavior were detected between the three groups on the first two trials (control: $N=16,8-0 \mathrm{H}-\mathrm{DPAT}: N=20$, WAY100635: $N=9$; ${ }^{* *} p<0.01$ Wilcoxon matched pairs test). across several species (Brown et al., 1982; Linnoila et al., 1983; Mehlman et al., 1994; Caramaschi et al., 2007; Clotfelter et al., 2007). Specifically, our findings suggest that it is at least partly the lack of sufficient tonic serotonin neurotransmission in these subjects that reduces their threshold to aggressive acts. This interpretation is consistent with recordings from serotonin neurons made in male tree shrews during antagonistic encounters. In this study serotonin neuron firing rates were reduced in dominant males and increased in subordinate males immediately before the encounter (Walletschek and Raab, 1982). We hypothesize that lower levels of extracellular serotonin in critical target tissues is insufficient to suppress the initiation of aggressive behavioral programs under social conditions in which they tend to be elicited. Thus, an important question for further study will be the precise neural circuits targeted by serotonin that mediate this altered threshold.

Notably, our findings appear to be at odds with pharmacological experiments in which Htrla agonists were delivered directly into the dorsal raphe nucleus of rats with the aim of suppressing serotonin neuron activity (Mos et al., 1993; De Almeida and Lucion, 1997; van der Vegt et al., 2003). Those studies reported significant reductions in aggression in the resident intruder test and were interpreted to support a role for serotonin in promoting aggression under nonescalated, baseline conditions. However, Htrla is expressed on serotonin and a subset of nonserotonin, GABA neurons in the raphe (Kirby et al., 2003; Marinelli et al., 2004; Bonnavion et al., 2010), and simultaneous inhibition of these two potentially antagonistic populations might underlie the behavioral findings reported. In contrast, our electrophysiological studies showed that agonist treatment of $\mathrm{Htrla}^{\mathrm{RR}}$ mice exclusively suppressed firing of serotonin neurons, leaving nonserotonin neurons unaffected (Fig. $7 H$ ). We hypothesize, then, that local GABA neurons are likely to play a critical role in modulating serotonin homeostasis and function.

Our findings do not support a role for serotonin activity in influencing the escalation of aggression as suggested by some studies (Fish et al., 1999; de Almeida and Miczek, 2002; Caramaschi et al., 2008). Htrla ${ }^{\mathrm{RO}}$ mice showed a similar decrease in latency to attack and increase in number of attacks across all three sessions (Fig. $3 B, C$ ). However, it remains to be determined whether acute reductions in serotonin at different stages of escalation might have differential effects on thresholds to aggression or whether more extended escalation of aggression could be differentially affected. It should be noted that the level of aggression elicited in the control strain we used was relatively low compared with that seen in some outbred strains (Parmigiani et al., 1999).

Our data also do not support a major role for the programming of adult aggression by developmental reduction in serotonin homeostasis. These findings seem to contradict pharmacological data showing that transient postnatal treatment with inhibitors of MAOA (Mejia et al., 2002) as well as hypomorphic alleles of MAOA (Brunner et al., 1993; Caspi et al., 2002; Mejia et al., 2002; KimCohen et al., 2006; Frazzetto et al., 2007) are associated with increased aggression and anti-social behavior. One possibility is that reduced degradation of serotonin by MAOA in these cases acts via a mechanism other than that modeled by the increased serotonin autoregulation seen in Htrla $a^{\mathrm{RO}}$ mice. Alternatively, an action of MAOA on nonserotonergic monoamine metabolism may play a critical role in the developmental programming of aggression by MAOA.

Strikingly, no effect of reducing serotonin neuron firing during either development or adulthood was seen on anxiety behavior in the open field test (Fig. $2 A-C$ ), consistent with the effects of 
other global reductions in serotonin (Savelieva et al., 2008), but seemingly at odds with the long-term effects of serotonin $1 \mathrm{~A}$ receptor signaling during development (Gross et al., 2002; Tsetsenis et al., 2007; Lo Iacono and Gross, 2008) and changes in anxiety reported following other genetic manipulations of the serotonin system (Hendricks et al., 2003). Thus, balanced regulation between multiple receptors must play a role in buffering the effects of global reductions in serotonin, at least for anxiety circuits.

Finally, subtle differences between the behavioral effects of chronic and acute reductions of serotonin neuron firing (e.g., only a trend for a reduction in latency to attack in the latter case, Fig. $5 B, C$ vs Fig. $8 A, B$ ) suggest that the aggressive phenotype of $H \operatorname{trl} a^{\mathrm{RO}}$ mice might be sustained in part by homeostatic mechanisms. For example, gradual sensitization and/or desensitization of Htrlb or Htrla autoreceptors or serotonin transporter function might amplify serotonergic deficits in $\mathrm{Htrla}^{\mathrm{RO}}$ mice (Chaput et al., 1986). It also may be that acute and chronic reductions in serotonin neuron firing moderate different aspects of aggression, with the latter having a stronger effect on impulsivity as reflected in shorter latencies to attack. Alternatively, the difference in attack latency could be explained by a difference in the amount of Htrla autoreceptor feedback available in the two animals, with higher feedback in $H \operatorname{trl} a^{\mathrm{RO}}$ mice conferring unique kinetics of firing during the social encounter that might reduce attack thresholds. Testing these hypotheses will require the use of neural silencing systems not dependent on serotonin signaling.

In summary, our data confirm a role of serotonin activity in setting thresholds for aggressive behavior and help clarify a longstanding controversy about the direction and causality of the association between serotonin and aggression. Future studies aimed at measuring the activity of serotonin neurons under pharmacogenetic or optogenetic control in awake behaving mice will shed light on the precise relationship between the firing dynamics of serotonin neurons and thresholds to aggression.

\section{References}

Allers KA, Sharp T (2003) Neurochemical and anatomical identification of fast- and slow-firing neurones in the rat dorsal raphe nucleus using juxtacellular labelling methods in vivo. Neuroscience 122:193-204. CrossRef Medline

Audero E, Coppi E, Mlinar B, Rossetti T, Caprioli A, Banchaabouchi MA, Corradetti R, Gross C (2008) Sporadic autonomic dysregulation and death associated with excessive serotonin autoinhibition. Science 321: 130-133. CrossRef Medline

Baraban JM, Aghajanian GK (1980) Suppression of firing activity of 5-HT neurons in the dorsal raphe by alpha-adrenoceptor antagonists. Neuropharmacology 19:355-363. CrossRef Medline

Bjork JM, Dougherty DM, Moeller FG, Cherek DR, Swann AC (1999) The effects of tryptophan depletion and loading on laboratory aggression in men: time course and a food-restricted control. Psychopharmacology 142:24-30. CrossRef Medline

Bonnavion P, Bernard JF, Hamon M, Adrien J, Fabre V (2010) Heterogeneous distribution of the serotonin 5-HT(1A) receptor mRNA in chemically identified neurons of the mouse rostral brainstem: Implications for the role of serotonin in the regulation of wakefulness and REM sleep. J Comp Neurol 518:2744-2770. Medline

Brown GL, Ebert MH, Goyer PF, Jimerson DC, Klein WJ, Bunney WE, Goodwin FK (1982) Aggression, suicide, and serotonin: relationships to CSF amine metabolites. Am J Psychiatry 139:741-746. Medline

Brunner HG, Nelen M, Breakefield XO, Ropers HH, van Oost BA (1993) Abnormal behavior associated with a point mutation in the structural gene for monoamine oxidase A. Science 262:578-580. CrossRef Medline

Caramaschi D, de Boer SF, Koolhaas JM (2007) Differential role of the 5-HT1A receptor in aggressive and nonaggressive mice: an across-strain comparison. Physiol Behav 90:590-601. CrossRef Medline

Caramaschi D, de Boer SF, de Vries H, Koolhaas JM (2008) Development of violence in mice through repeated victory along with changes in prefrontal cortex neurochemistry. Behav Brain Res 189:263-272. CrossRef Medline

Caspi A, McClay J, Moffitt TE, Mill J, Martin J, Craig IW, Taylor A, Poulton R (2002) Role of genotype in the cycle of violence in maltreated children. Science 297:851-854. CrossRef Medline

Chamberlain B, Ervin FR, Pihl RO, Young SN (1987) The effect of raising or lowering tryptophan levels on aggression in vervet monkeys. Pharmacol Biochem Behav 28:503-510. CrossRef Medline

Chaput Y, de Montigny C, Blier P (1986) Effects of a selective 5-HT reuptake blocker, citalopram, on the sensitivity of 5-HT autoreceptors: electrophysiological studies in the rat brain. Naunyn Schmiedebergs Arch Pharmacol 333:342-348. CrossRef Medline

Clotfelter ED, O’Hare EP, McNitt MM, Carpenter RE, Summers CH (2007) Serotonin decreases aggression via 5-HT1A receptors in the fighting fish Betta splendens. Pharmacol Biochem Behav 87:222-231. CrossRef Medline

De Almeida RM, Lucion AB (1997) 8-OH-DPAT in the median raphe, dorsal periaqueductal gray and corticomedial amygdala nucleus decreases, but in the medial septal area it can increase maternal aggressive behavior in rats. Psychopharmacology 134:392-400. CrossRef Medline

de Almeida RM, Miczek KA (2002) Aggression escalated by social instigation or by discontinuation of reinforcement ("frustration") in mice: inhibition by anpirtoline: a 5-HT1B receptor agonist. Neuropsychopharmacology 27:171-181. CrossRef Medline

de Boer SF, Koolhaas JM (2005) 5-HT1A and 5-HT1B receptor agonists and aggression: a pharmacological challenge of the serotonin deficiency hypothesis. Eur J Pharmacol 526:125-139. CrossRef Medline

de Boer SF, Lesourd M, Mocaër E, Koolhaas JM (2000) Somatodendritic 5-HT(1A) autoreceptors mediate the anti-aggressive actions of 5-HT(1A) receptor agonists in rats: an ethopharmacological study with S-15535, alnespirone, and WAY-100635. Neuropsychopharmacology 23:20-33. CrossRef Medline

de Kock CP, Cornelisse LN, Burnashev N, Lodder JC, Timmerman AJ, Couey JJ, Mansvelder HD, Brussaard AB (2006) NMDA receptors trigger neurosecretion of 5-HT within dorsal raphe nucleus of the rat in the absence of action potential firing. J Physiol 577:891-905. CrossRef Medline

Fish EW, Faccidomo S, Miczek KA (1999) Aggression heightened by alcohol or social instigation in mice: reduction by the $5-\mathrm{HT}(1 \mathrm{~B})$ receptor agonist CP-94,253. Psychopharmacology 146:391-399. CrossRef Medline

Frazzetto G, Di Lorenzo G, Carola V, Proietti L, Sokolowska E, Siracusano A, Gross C, Troisi A (2007) Early trauma and increased risk for physical aggression during adulthood: the moderating role of MAOA genotype. PLoS One 2:e486. CrossRef Medline

Gross C, Zhuang X, Stark K, Ramboz S, Oosting R, Kirby L, Santarelli L, Beck S, Hen R (2002) Serotonin1A receptor acts during development to establish normal anxiety-like behaviour in the adult. Nature 416:396-400. CrossRef Medline

Hendricks TJ, Fyodorov DV, Wegman LJ, Lelutiu NB, Pehek EA, Yamamoto B, Silver J, Weeber EJ, Sweatt JD, Deneris ES (2003) Pet-1 ETS gene plays a critical role in 5-HT neuron development and is required for normal anxiety-like and aggressive behavior. Neuron 37:233-247. CrossRef Medline

Huang YY, Cate SP, Battistuzzi C, Oquendo MA, Brent D, Mann JJ (2004) An association between a functional polymorphism in the monoamine oxidase a gene promoter, impulsive traits and early abuse experiences. Neuropsychopharmacology 29:1498-1505. CrossRef Medline

Kim-Cohen J, Caspi A, Taylor A, Williams B, Newcombe R, Craig IW, Moffitt TE (2006) MAOA, maltreatment, and gene-environment interaction predicting children's mental health: new evidence and a meta-analysis. Mol Psychiatry 11:903-913. CrossRef Medline

Kirby LG, Pernar L, Valentino RJ, Beck SG（2003） Distinguishing characteristics of serotonin and nonserotonin-containing cells in the dorsal raphe nucleus: electrophysiological and immunohistochemical studies. Neuroscience 116:669-683. CrossRef Medline

Kistner A, Gossen M, Zimmermann F, Jerecic J, Ullmer C, Lübbert H, Bujard H (1996) Doxycycline-mediated quantitative and tissue-specific control of gene expression in transgenic mice. Proc Natl Acad Sci U S A 93:1093310938. CrossRef Medline

Kung MP, Frederick D, Mu M, Zhuang ZP, Kung HF (1995) 4-(2'Methoxy-phenyl)-1-[2'-(n-2“'-pyridinyl)-p-iodobenzamido]-ethylpiperazine ([125I]p-MPPI) as a new selective radioligand of serotonin-1A 
sites in rat brain: in vitro binding and autoradiographic studies. J Pharmacol Exp Ther 272:429-437. Medline

Li YQ, Li H, Kaneko T, Mizuno N (2001) Morphological features and electrophysiological properties of serotonergic and nonserotonergic projection neurons in the dorsal raphe nucleus. An intracellular recording and labeling study in rat brain slices. Brain Res 900:110-118. CrossRef Medline

Linnoila M, Virkkunen M, Scheinin M, Nuutila A, Rimon R, Goodwin FK (1983) Low cerebrospinal fluid 5-hydroxyindoleacetic acid concentration differentiates impulsive from nonimpulsive violent behavior. Life Sci 33:2609-2614. CrossRef Medline

Lo Iacono L, Gross C (2008) Alpha- $\mathrm{Ca}^{2+} /$ calmodulin-dependent protein kinase II contributes to the developmental programming of anxiety in serotonin receptor 1A knock-out mice. J Neurosci 28:6250-6257. CrossRef Medline

Manuck SB, Flory JD, Ferrell RE, Dent KM, Mann JJ, Muldoon MF (1999) Aggression and anger-related traits associated with a polymorphism of the tryptophan hydroxylase gene. Biol Psychiatry 45:603-614. CrossRef Medline

Marinelli S, Schnell SA, Hack SP, Christie MJ, Wessendorf MW, Vaughan CW (2004) Serotonergic and nonserotonergic dorsal raphe neurons are pharmacologically and electrophysiologically heterogeneous. J Neurophysiol 92:3532-3537. CrossRef Medline

Martin KF, Phillips I, Hearson M, Prow MR, Heal DJ (1992) Characterization of 8-OH-DPAT-induced hypothermia in mice as a 5-HT1A autoreceptor response and its evaluation as a model to selectively identify antidepressants. Br J Pharmacol 107:15-21. CrossRef Medline

Mehlman PT, Higley JD, Faucher I, Lilly AA, Taub DM, Vickers J, Suomi SJ, Linnoila M (1994) Low CSF 5-HIAA concentrations and severe aggression and impaired impulse control in nonhuman primates. Am J Psychiatry 151:1485-1491. Medline

Mejia JM, Ervin FR, Baker GB, Palmour RM (2002) Monoamine oxidase inhibition during brain development induces pathological aggressive behavior in mice. Biol Psychiatry 52:811-821. CrossRef Medline

Miczek KA, Hussain S, Faccidomo S (1998) Alcohol-heightened aggression in mice: attenuation by 5-HT1A receptor agonists. Psychopharmacology 139:160-168. CrossRef Medline

Mlinar B, Tatini F, Ballini C, Nencioni S, Della Corte L, Corradetti R (2005) Differential autoinhibition of 5-hydroxytryptamine neurons by 5 -hydroxytryptamine in the dorsal raphe nucleus. Neuroreport 16:1351-1355. CrossRef Medline

Mos J, Olivier B, Poth M, Van Oorschot R, Van Aken H (1993) The effects of dorsal raphe administration of eltoprazine, TFMPP and 8-OH-DPAT on resident intruder aggression in the rat. Eur J Pharmacol 238:411-415. CrossRef Medline

Newman TK, Syagailo YV, Barr CS, Wendland JR, Champoux M, Graessle M, Suomi SJ, Higley JD, Lesch KP (2005) Monoamine oxidase A gene pro- moter variation and rearing experience influences aggressive behavior in rhesus monkeys. Biol Psychiatry 57:167-172. CrossRef Medline

Osipova DV, Kulikov AV, Popova NK (2009) C1473G polymorphism in mouse tph2 gene is linked to tryptophan hydroxylase-2 activity in the brain, intermale aggression, and depressive-like behavior in the forced swim test. J Neurosci Res 87:1168-1174. CrossRef Medline

Parmigiani S, Palanza P, Rogers J, Ferrari PF (1999) Selection, evolution of behavior and animal models in behavioral neuroscience. Neurosci Biobehav Rev 23:957-969. CrossRef Medline

Ramboz S, Oosting R, Amara DA, Kung HF, Blier P, Mendelsohn M, Mann JJ, Brunner D, Hen R (1998) Serotonin receptor 1A knockout: an animal model of anxiety-related disorder. Proc Natl Acad Sci U S A 95:14476-14481. CrossRef Medline

Saudou F, Amara DA, Dierich A, LeMeur M, Ramboz S, Segu L, Buhot MC, Hen R (1994) Enhanced aggressive behavior in mice lacking 5-HT1B receptor. Science 265:1875-1878. CrossRef Medline

Savelieva KV, Zhao S, Pogorelov VM, Rajan I, Yang Q, Cullinan E, Lanthorn TH (2008) Genetic disruption of both tryptophan hydroxylase genes dramatically reduces serotonin and affects behavior in models sensitive to antidepressants. PLoS One 3:e3301. CrossRef Medline

Schneider R, Hoffmann HJ, Schicknick H, Moutier R (1992) Genetic analysis of isolation-induced aggression. I. Comparison between closely related inbred mouse strains. Behav Neural Biol 57:198-204. CrossRef Medline

Tsetsenis T, Ma XH, Lo Iacono L, Beck SG, Gross C (2007) Suppression of conditioning to ambiguous cues by pharmacogenetic inhibition of the dentate gyrus. Nat Neurosci 10:896-902. CrossRef Medline

van der Vegt BJ, Lieuwes N, van de Wall EH, Kato K, Moya-Albiol L, Martínez-Sanchis S, de Boer SF, Koolhaas JM (2003) Activation of serotonergic neurotransmission during the performance of aggressive behavior in rats. Behav Neurosci 117:667-674. CrossRef Medline

Vandermaelen CP, Aghajanian GK (1983) Electrophysiological and pharmacological characterization of serotonergic dorsal raphe neurons recorded extracellularly and intracellularly in rat brain slices. Brain Res 289:109-119. CrossRef Medline

Vergnes M, Depaulis A, Boehrer A (1986) Parachlorophenylalanineinduced serotonin depletion increases offensive but not defensive aggression in male rats. Physiol Behav 36:653-658. CrossRef Medline

Virkkunen M, Rawlings R, Tokola R, Poland RE, Guidotti A, Nemeroff C, Bissette G, Kalogeras K, Karonen SL, Linnoila M (1994) CSF biochemistries, glucose metabolism, and diurnal activity rhythms in alcoholic, violent offenders, fire setters, and healthy volunteers. Arch Gen Psychiatry 51:20-27. CrossRef Medline

Walletschek H, Raab A (1982) Spontaneous activity of dorsal raphe neurons during defensive and offensive encounters in the tree-shrew. Physiol Behav 28:697-705. CrossRef Medline 